\title{
THE CONCEPTS OF NOSARARA NOSABATUTU IN THE KAILI COMMUNITY: INSPIRATION FOR RELIGIOUS HARMONY IN INDONESIA
}

\author{
Dwi Septiwiharti, Septiana Dwiputri Maharani, Rizal Mustansyir \\ Faculty of Philosophy, Universitas Gadjah Mada \\ Jalan Olahraga, Bulaksumur, Yogyakarta - 55281, Indonesia \\ e-mail: dwiseptiwiharti@gmail.com
}

\begin{abstract}
This article aims to describe the local wisdom and values of Nosarara Nosabatutu in the Kaili community in Central Sulawesi using an axiological perspective as an inspiration for religious harmony in Indonesia. This research employs a qualitative method in the field of philosophical axiology. The object of research material is the teaching of nosarara nosabatutu, and the formal object is the theory of objectivism of values. The analysis shows that family values are at the vital value level, while the value of unity is at the spiritual value level in the Schelerian hierarchy. Both values indicate spiritual sentiments and spiritual preferences. Nosarara teaches individuals to love others as their brothers, as reflected Kaili's term of sararata le or sararata ia which means s/he is a family. Spiritual nosabatutu teaches one to take care of the family property as shared wealth and also keep other people's secrets because everyone in the Kaili ethnic group comes from the same womb and lives from the same treasure as a family.
\end{abstract}

Keywords:

Kaili; nosarara nosabatutu; family; values; solidarity; objectivism.

\begin{abstract}
Abstrak
Artikel ini bertujuan utnuk mendeskripsikan nilai-nilai nosarara nosabatutu masyarakat Kaili di Sulawesi Tengah dalam perspektif aksiologi sebagai inspirasi bagi persoalan keberagamaan di Indonesia. Penelitian ini merupakan penelitian kualitatif bidang filsafat khususnya aksiologi. Objek material penelitian adalah ajaran nosarara nosabatutu, dan objek formalnya adalah teori objektivisme nilai. Hasil analisis menunjukkan bahwa nilai kekeluargaan berada pada tingkat nilai vital, sedangkan nilai persatuan berada pada tingkat nilai spiritual dalam hierarki Schelerian. Kedua nilai tersebut menunjukkan adanya sentimen spiritual dan preferensi spiritual. Nosarara mengajarkan individu untuk mencintai orang lain sebagai saudara sendiri, sebagaimana tercermin dalam terminologi Kaili sararata le atau sararata ia yang berarti dia adalah saudara. Spiritualitas nosabatutu mengajarkan seseorang untuk merawat harta keluarga sebagai kekayaan bersama dan juga menjaga rahasia orang lain karena semua orang dalam etnik Kaili berasal dari rahim yang sama dan hidup dari harta yang sama sebagai sebuah keluarga.
\end{abstract}

Kata Kunci:

Kaili; nosarara nosabatutu; kekeluargaan; nilai; persatuan; objektivisme.

DOI: $10.15575 / \mathrm{jw} . v 4 \mathrm{i} 2.6622$

Received: August 2019; Accepted: December 2019; Published: December 2019 
Dwi Septiwiharti, Septiana Dwiputri Maharani, Rizal Mustansyir

\section{A. INTRODUCTION}

Indonesia is a highly sophisticated culture, with constituent elements coming from such diverse ethnic groups as the Javanese, Sundanese, Balinese, Minangkabau, Batak, Buginese, Torajans, Mandar, Kaili, and many others. Kaili is one of the twelve recognized ethnic groups in Central Sulawesi; other Central Sulawesian peoples include Tomini, Kulawi, Pamona, Lore, Mori, Bungku, Saluan, Balantak, Banggai, Tolitoli, and Buol. ${ }^{1}$ The Kaili, who identify themselves as To Kaili, ${ }^{2}$ is an indigenous of Central Sulawesi, including Palu, Sirenja, Sindue, Tawaeli, Sigi, Biromaru, Dolo, Marawola, Banawa, Parigi, Dampelas, and Balaisang; migrant Kaili also spread in East Kalimantan and Java. ${ }^{3}$ Kaili culture, meanwhile, is that culture practiced by the Kaili of Central Sulawesi.

The most prominent element of Kaili culture is solidarity, as Kaili communities tend to be united by strong social bonds. ${ }^{4}$ One tradition maintained by the Kaili is nosarara nosabatutu, a principle that promotes a sense of pan-Kaili kinship and unity. ${ }^{5}$ This principle has been maintained and practiced by the Kaili for centuries, and remains the basis of social harmony in modern Kaili society. Nosarara nosabatutu embodies values of kinship, unity, and shared responsibility. In conjunction with other elements of local wisdom, including $a d a$ nosibolai, libu ntodea, sintuvu, nopakasongu, and tonda talusi, it continues to structure Kaili. According to the principle of nosara

${ }^{1}$ Budi Kristanto, Suku Bangsa Kaili Dari Sejarah Hingga Budayanya (Manado: Center for the Study of History and Traditional Values, 2002).

${ }^{2}$ H.A. Mattulada, "Manusia Dan Kebudayaan Kaili Di Sulawesi Tengah," Majalah Ilmiah Gagasan, no. 3 (1985).

${ }^{3}$ Junus Melalatoa, Ensiklopedi Suku Bangsa Di Indonesia (Jakarta: C.V. Eka Putra, 1995).

${ }^{4}$ H.A. Mattulada, Modal Personality Orang Kaili (Palu: Universitas Tadulako, 1989).

${ }^{5}$ B Ratu, Misnah Misnah, and M Amirullah, "Peace Education Based on Local Wisdom Nosarara Nosabatutu," JOMSIGN: Journal of Multicultural Studies in Guidance and Counseling 3, no. 2 (n.d.): 106118.
The Concepts of Nosarara Nosabatutu in the Kaili Community: Inspiration for Religious Harmony in Indonesia

nosabatutu, the Kaili people understand themselves as sharing the same lineage (nosarara), and as such, they view themselves as members of a single-family. These kinship bonds are manifested within a family unit known as batutu, a central component of the nosabatutu concept. The values embodied within the principle of nosarara nosabatutu are fundamental to reaffirming the third tenet of Pancasila, Indonesia's national ideology: Indonesian unity.

In recent years, Indonesia has experienced a surge of conflict and radicalism. Various cases of inter-ethnic conflict have occurred, including the Dayak-Madurese conflict of West Kalimantan, ${ }^{6}$ the Sentani-Butonese conflict of Papua, ${ }^{7}$ the trilateral AcehneseBatak-Minang conflict in Medan, ${ }^{8}$ and the Madurese-Javanese conflict in Bali. Mamar attributes these inter-ethnic conflicts to the increased marginalization of local values in Indonesian society. ${ }^{9}$ Indonesians have forgotten the ancestral values that guided their ancestors in maintaining social harmony and bonds. Harmony and solidarity have taken an increasingly minimal role in Indonesian society, as Indonesians have failed to incorporate and reflect on their traditional local values, turning instead to their primordial and ethnic identities. Conflict, thus, has been inevitable. It is necessary for local values and wisdoms to be actualized in Indonesian society.

Another factor that has influenced the erosion of local values is globalization. ${ }^{10}$

\footnotetext{
${ }^{6}$ Anika König, "Identity Constructions and Dayak Ethnic Strife in West Kalimantan, Indonesia," The Asia Pacific Journal of Anthropology 17, no. 2 (2016): 121137.

${ }^{7} \mathrm{~F}$ Faisal et al., "From Conflict to Assimilation: Strategies of Muslim Immigrants in Papua Special Autonomy Era," Wawasan: Jurnal Ilmiah Agama Dan Sosial Budaya 4, no. 1 (2019): 103-116.

${ }^{8}$ Ida Liana Tanjung, Bambang Purwanto, and Nur Aini Setyawati, "Colonial Politics in Forming Ethnic Identity of Melayu Minangkabau and Batak in Tapanuli," Jurnal Humaniora 28, no. 1 (2016): 106-114.

${ }^{9}$ Sulaiman Mamar, Perspektif Budaya (Jakarta: Rajawali Pers, 2009).

${ }^{10}$ A K M Ahsan Ullah and Hannah Ming Yit Ho, "Globalisation and Cultures in Southeast Asia: Demise,
} 
Dwi Septiwiharti, Septiana Dwiputri Maharani, Rizal Mustansyir

Indonesia's youths have faced the significant challenge of modernization as science and technology have advanced. Although technological advances have had both positive and negative effects on social behaviors and activities, the negative consequences of materialism and individualism have been particularly prominent. ${ }^{11}$ Advances in communication and information technology should be balanced with local values, so that the harmful effects of materialism and individualism can be avoidable. Youths should not become strangers of their cultural origin, ignorant of Indonesia's multiculturalism and diversity. To ensure that Indonesia's youths are not swept away by the changes wrought by globalization, a better understanding of local values and wisdom is urgent and relevant.

Sudarminta explains that human beings are always motivated by their values. As such, human beings cannot exist without values, without the qualities and attitudes that make something desirable, honorable, and attractive. ${ }^{12}$ Values offer guidance, influence the course of human lives, and thereby shape humans' identities and "fates." It is essential to recognize that the everyday manifestation of a value system in social life does not objectively reflect the value system. In other words, values are not practiced in their ideal form, but cultivated and subjectively interpreted within particular social communities. Maintaining local values and wisdom is central to improving a national culture; in turn, culture provides a nation with the means to develop and advance itself. For example, President Sukarno identified as berkepribadian dalam kebudayaan-building character through culture. Akin to human beings, a nation can only establish its dignity based on a good character, a character that acquired through national culture. Without such a character, a
The Concepts of Nosarara Nosabatutu in the Kaili Community: Inspiration for Religious Harmony in Indonesia country-such as Indonesia-will become weak and fragmented, with citizens lacking any sense of pride or sense of belonging.

For the Kaili people, the concept of nosarara nosabatutu embodies a sense of solidarity and togetherness. Within this concept, all Kaili people identified themselves as sharing the same genealogical lineage (a single bloodline, or nosarara). All members of this shared lineage are united in one family unit or batutu; this provides the etymological root for nosabatutu. The principle of nosarara nosabatutu is as old as the Kaili people themselves and is understood as a principle for creating solidarity and mutual concern. Under the traditional system, each Kaili group was led by an elder or chief (tomalanggai), who promoted togetherness and solidarity through nosarara nosabatutu. As such, the principle of nosarara nosabatutu can be defined ideally as involving shared living, solidarity, unity, and accountability; for them, it represents a social and ethical value. Building on this background, the current study will examine nosarara nosabatutu as a guiding principle of everyday life. The analysis of this study utilizes Max Scheler's theory of the hierarchy of values and axiological objectivism. ${ }^{13}$

The material object of this study is nosarara nosabatutu as a Kaili cultural value and principle, while the formal analysis of this study is Max Scheler's value objectivism. This research is library research, particularly a review of books and other literature that are relevant to the material and formal object. These resources were then interpreted, with the results of interpretation providing the basis for this article.

The axiological study of value has shown two predominant tendencies, namely subjectivism and objectivism. Etymologically, subjectivism is derived from the word 'subject',

\footnotetext{
${ }^{12}$ Paulus Wahana, Nilai Etika Aksiologi Max Scheler (Yogyakarta: Kanisius, 2004).

${ }^{13}$ Max Scheler, Der Formalismus in Der Ethik Und Die Materiale Wertehik (Halle: Verlag von Max Niemeyer, 1916).
}

Fragmentation, Transformation," Global Society, 2020 $-16$

Helen I Duh, "Antecedents and Consequences of . An Integrated Theoretical Framewor Journal of Economics and Behavioral Studies 7, no. 1 (2015): 20-35. 
Dwi Septiwiharti, Septiana Dwiputri Maharani, Rizal Mustansyir

to be 'subjective'. While objectivism is derived from the word 'object,' focuses on the 'object', and offers the 'objective.' There are four understandings of axiological objectivism, namely: (a) values exist independently of how one understands them; (b) values can be identified and recognized; (c) values must be applied by human beings in their evaluations and their behaviors; (d) objects or activities become valuable or correct because of objective components, which are accepted based on how they are perceived, experienced, or felt. ${ }^{14}$

Max Scheler, a major proponent of objectivism, argues that values have their own independent, or a priori, qualities. This study employs Scheler's theory of axiological objectivism to analyze cultural values and principles of nosarara nosabatutu. Scheler believes that values are organized in an a priori hierarchy, with particular values being prioritized over others through specific 'preferences' (i.e., activities of the consciousness). Axiology, thus, focuses on the preferences that underlie values and value systems. 'Preference' should not be confused with 'choice'; choice refers to a tendency, while preference is something consciously recognized, the result of a conscious decision. As such, the hierarchy of values is not shaped by human desires but exists independently of them. ${ }^{15}$

According to Scheler, values exist within a particular a priori structure, with certain values being prioritized over others through specific 'preferences' (i.e., activities of the consciousness) rather than empirical criteria. Scheler categorizes preferences criteria to the following: 1) the ability of a value to endure and survive; 2) the divisibility of a value, with values that are higher in the hierarchy being less divisible; 3) fundamentality, with values that are higher in the hierarchy being more

\footnotetext{
${ }^{14}$ Lorens Bagus, Kamus Filsafat (Jakarta: Gramedia Pustaka Utama, 1996).

${ }^{15} \mathrm{R}$ Frondizi, What Is Value? An Introduction to Axiology (Chicago: Open Court Publishing Company, 1971).
}

The Concepts of Nosarara Nosabatutu in the Kaili Community: Inspiration for Religious Harmony in Indonesia

fundamental; 4) satisfaction, specifically sentimental satisfaction with a particular value (rather than a sentimental satisfaction with another value; 'satisfaction' should not be confused with 'pleasure' or 'enjoyability', even though 'pleasure' may be derived from satisfaction); and 5) relativity, which references the essence of the value itself; values that are less relative (more absolute) are higher in the hierarchy. The highest of all values are absolute values, which are, by definition, more enduring and satisfactory than dynamic values. $^{16}$

Using these criteria, Scheler identifies a hierarchy of values as follows. ${ }^{17}$ First, at the lowest level, those pleasures and displeasures that are created through worldly and sensory joys and sorrows. Joy is prioritized over pain, pleasure over displeasure, not through observation or induction, but rather because of the value's own a priori condition. It can be determined objectively, thus, that all persons will prefer joy over sorrow, and will make decisions that maximize pleasure (rather than make decisions that maximize displeasure).

At the second level are the vital values, which do not depend on and cannot be reduced to pleasure and displeasure, but rather are life values. These may include the noble and the refined, or the ignoble and the rough. This level also includes values of good and evil. Values at this level tend to contribute to public welfare, including at the community level and the personal level, and may include health, vitality, disease, age, strength, and foreboding. These values are not dependent on, or reduced to higher values (i.e., spiritual values) or lower values (i.e., practical/pleasure values).

Third are spiritual values, for which pleasure and vital values must be sacrificed. Spiritual values are entirely independent of the body and the physical environment. Spiritual values are prioritized over pleasure and vital values,

\footnotetext{
${ }^{16}$ Wahana, Nilai Etika Aksiologi Max Scheler.

${ }^{17}$ Frondizi, What Is Value? An Introduction to Axiology.
} 
Dwi Septiwiharti, Septiana Dwiputri Maharani, Rizal Mustansyir

which are thus sacrificed for them. Spiritual values must be understood through 'spiritual' means, particularly preferences for 'love' and 'hate'; such values cannot be reduced to the biological or physical. This level can be further divided into: (a) aesthetic values (beauty, ugliness, etc.); (b) values of justice and injustice; (c) values of the 'pure knowledge of the truth' sought by philosophy and of positive sciences (these must be distinguished from correctness and incorrectness, which are not part of the value system. Unlike correctness and incorrectness, scientific and cultural values, as well as the knowledge that they embody, become values through reference).

Fourth are sacred values, which exist at the highest level of the hierarchy. These values cannot be reduced to the spiritual, but exist as absolute and independent values. These values may include, for example, deep ecstasy and desperation that refer to the sacral. Love is a means of capturing such values.

\section{B. RESULTS AND DISCUSSION}

\section{Nosarara Nosabatutu as a Kaili Cultural Value}

Human beings and human life cannot be separated from their values. Consciously or subconsciously, humans are always influenced by their interactions with each other and their environments. ${ }^{18}$ As social beings, humans always interact with their surroundings, including their natural and cultural environments. Kluckhohn and Strodback explore the connection between values and culture more explicitly. Michael D. Hills, in his article "Kluckhohn and Strodback's Values Orientation Theory," explains that values are used to address universal issues and answer universal questions. He writes: ${ }^{19}$

\footnotetext{
${ }^{18}$ Bambang Daroeso, Dasar Dan Konsep Pendidikan Moral Pancasila (Semarang: Aneka Ilmu, 1986).

${ }^{19}$ Michael D Hills, "Kluckhohn and Strodtbeck's Values Orientation Theory," Online Readings in Psychology and Culture, no. 4 (2002), https://doi.org/10.9707/2307-0919.1040.
}

The Concepts of Nosarara Nosabatutu in the Kaili Community: Inspiration for Religious Harmony in Indonesia

There is a limited number of common human problems for which all peoples must at all times find some solution;"

While there is variability in solutions of all the problems, it is neither limitless nor random but is variable within a range of possible solutions;

All alternatives of all solutions are present in all societies at all times but are differentially preferred.

Kluckhohn and Strodback explain that value orientations always depart from human beings' efforts to answer fundamental questions. Social groups may reflect on these questions differently, distinguishing themselves from each other, but depart from the same four questions: about time, about the connection between humans and their environment, about the interactions between human beings, and the motivations for human behavior. Time is always seen within three contexts: the past, the present, and the future. Meanwhile, the connection between humans and the environment is examined through questions of extra-human being, of harmony, and of submissiveness. In their interactions, human beings are seen as not only having a linear hierarchy but also as sharing certain similarities. Finally, the motive is linked to one's internal motivations and one's desire for self-development. ${ }^{20}$

In his Universal Categories of Culture (1963), Kluchohn identifies several universal elements of culture: a system of religion, a system of knowledge, a system of technology (tools and implements), a system of economics (economic behaviors and livelihoods), a system of society (social rules and kinship systems), language (a tool for communication), and a system of art. According to Kluchohn, every culture has these systems, which tend to differ significantly from each other. ${ }^{21}$ Within this

\footnotetext{
${ }^{20}$ Hills, "Kluckhohn and Strodtbeck's Values Orientation Theory."

${ }^{21}$ Clyde Kluckhohn, "Universal Categories of Culture," in Culture: A Critical Review of Concepts and Definitions, ed. \& A. G. Meyer A. L. Kroeber, C.
} 
Dwi Septiwiharti, Septiana Dwiputri Maharani, Rizal Mustansyir
The Concepts of Nosarara Nosabatutu in the Kaili Community: Inspiration for Religious Harmony in Indonesia framework, nosarara nosabatutu - as part of Kaili culture that incorporates kinship and unity values - may thus be categorized as a system of society.

The Kaili principle of nosarara nosabatutu teaches that family (nosarara) and solidarity (nosabatutu) are necessary to create harmony. As such, it contains important values that are oriented towards promoting social welfare. Since nosarara nosabatutu belongs to the inclusion of family values, nosarara nosabatutu also includes spiritual sentiments and preferences. One example of the spiritual sentiments and preferences embodied within the nosarara concept is the belief that one must love others as one loves one's own family, as seen in the phrases "sararata le"/"sararata ia" (our brother/our sister). Spiritual values are also contained within the Kaili concept of nosabatutu. Haliadi, ${ }^{22}$ mentions that this concept underscores a shared fate, a mutual respect, an ability to keep secrets, an ability to maintain community resources for mutual interests, and a respect for caution. The principle of nosarara nosabatutu shows that the Kaili have prioritized harmony and unity as spiritual values; in other words, this principle has become deeply embedded within Kaili culture and society. Through the principle of nosarara nosabatutu, the Kaili has created a sense of family and solidarity, and ultimately a concept of sintuvu - of unity through deliberation (libu ntodea).

Nosarara nosabatutu, an oral tradition that has developed among the Kaili people, is understood and practiced in their everyday lives. Orality refers to a process in which messages and ideas are passed through repetition over generations. ${ }^{23}$ As stated by Gazali, the expressions of oral tradition are rooted in experiences, in reflection on everyday problems, as filtered through culture. ${ }^{24}$ Nosarara nosabatutu is similarly a product of cultural reflection on everyday problems and issues, one that has informed the world view of the Kaili people and been manifested in various elements of social life. The principle of nosarara nosabatutu can be traced back to the Tomalanggai era before Central Sulawesi's first kingdoms (kemagauan) were established; it thus predates the Tatanga Kingdom, the Besusu Kingdom, the Banawa Kingdom, the Sigi Kingdom, and the Palu Kingdom. ${ }^{25}$ The Kaili principle of solidarity and togetherness continued to develop over time through traditional rituals and activities, during which cultural institutions promote discursive and deliberative problem-solving. Discourse and deliberation are evident in norms, sanctions ( givu), and other elements of community living (weddings, thanksgiving ceremonies, etc.). The results of libu ntodea-of deliberative discussions - have and continue to be obeyed and respected by the Kaili people. ${ }^{26}$

\section{Meaning of Nosarara Nosabatutu in Kaili Culture}

The Kaili people view balance as a necessary and natural part of human life, and their principle of Nosarara nosabatutu embodies and manifests the harmony value that underpins their everyday lives. In his article "Kearifan Lokal Masyarakat Kaili di Sulawesi Tengah," Saleh writes that the Kaili people prioritize balance in their daily lives, and thus attempt to avoid conflict. ${ }^{27}$ They view balance as a means of preventing conflict and of maintaining harmony between all elements of the universe, including society. As such, nosarara nosabatutu is found in all parts of
Kluckhohn, W. Untereiner (New York: Vintage Books, 1963).

${ }^{22}$ Haliadi, Nosarara Nosabatutu (Yogyakarta: Yogyakarta: Nuansa Aksara, 2008).

${ }^{23}$ Jan Vansina, Tradisi Lisan Sebagai Sejarah (Yogyakarta: Ombak, 2014).

${ }^{24}$ Dunia Gazali, Sejarah Dan Telaah Sastra Indonesia (Jakarta: Wijaya, 1971).

\footnotetext{
${ }^{25}$ Suaib Djafar, Mengenal Adat Kaili Di Sulawesi Tengah (Yogyakarta: Ombak, 2012).

${ }^{26}$ Djafar, Mengenal Adat Kaili Di Sulawesi Tengah.

${ }^{27}$ Sukmawati Saleh, "Kearifan Lokal Masyarakat Kaili Di Sulawesi Tengah," Jurnal Academica 5, no. 2 (2013): 1126-1134.
} 
Dwi Septiwiharti, Septiana Dwiputri Maharani, Rizal Mustansyir

Kaili society, thereby providing a basis for and driving social harmony.

Evans defines nosarara as 'feeling,' 'emotion,' or 'sense,' while batutu refers to a cloth bag or sack. Etymologically, the word nosarara consists of no ('to be'), sa ('one'), and rara ('heart,' 'feeling'); it thus may be understood as 'to be [of] one heart.'28 Meanwhile, the term nosabatutu consists of no ('to be'), sa ('one'), and batutu ('cloth bag/sack'); it may thus be understood as 'to share one cloth bag/sack.' Traditionally, batutu were used to store valuable goods, secret items, or other implements. In the Kaili Rai language, the term batutu can also denote a mother's womb. By breaking down the phrase nosarara nosabatutu, it can thus be defined as a perspective and sense of belonging (kinship and solidarity) that is shared amongst all members of a community. Such a principle is of paramount importance for Indonesia's multiethnic and multi-cultural society, as it will prevent - or at least minimize - conflicts that could threaten national integrity.

Etymologically, the term nosarara contains within it the word sarara ('family'). Family can be defined in three ways: 1) members of the same household, 2) siblings and kin, and 3) marital partners (i.e., husbands and wives); sarara refers to the family as kin, as siblings. Nosarara carries several connotations, including 1) nosangurara (heart), 2) nosanguraa (blood), and nosampesuvu (kin); all of these imply a family, a community, that comes from the same womb.29 The word nosabatutu incorporates the word batutu ('cloth bag/sack'), as well as the prefixes no ('to') and sa ('one'); as such, the word nosabatutu means 'to share the same cloth sack.' Haliadi shows that nosarara nosabatutu contains a commitment to shared living through (1) a strong sense of kinship; (2) an unbreakable social bond; (3) a sense of togetherness known
The Concepts of Nosarara Nosabatutu in the Kaili Community: Inspiration for Religious Harmony in Indonesia

locally as sintuvu (agreement); (4) a united family; (5) a sense of shared responsibilities; (6) a dedication to maintaining existing resources, including natural, environmental, and personal resources, and using said resources to promote the greater good; (7) a sense of secrecy; (8) a sense of caution. Nosarara nosabatutu constructively frames social heterogeneity as an essential part of maintaining harmony and solidarity. It understands unity within the family as necessary for creating harmony in society. ${ }^{30}$

Chalid explored the principle of nosarara nosabatutu using a sociological and cultural approach. ${ }^{31}$ In his study "Nosarara Nosabatutu (Makna dan Konsep Sosiologis-Kultural To Kaili)," Chalid equated nosarara with nosalara (pain), while nosabatutu is widely found in all Kaili dialects. Nosarara refers to family bonds, while nosabatutu is understood as a community that uses shared resources to promote its shared interests.

\section{Nosarara Nosabatutu within a Schelerian Perspective: an Inspiration for Religious Harmony}

The term objectivism is grammatically linked to the word object (n) and objective (adj.) that denotes a perspective related to objects. Unlike subjectivism, which refers to the subject, objectivism refers to the object. Axiological objectivists view values as things that exist independently and identifiable. Values are independent of their observers and offer particular qualities that inform individuals' sense of morality and beauty while shaping their decisions and preferences. Generally, individuals prioritize objects and experiences that they find valuable. Values are not created through observation, but rather exist independently of it. As such, when an axiological objectivist sees a painting, will say 'that painting captivates me' rather than 'that

\footnotetext{
${ }^{30}$ Haliadi, Nosarara Nosabatutu.

${ }^{31}$ Syamsuddin H. Chalid, Nosarara Nosabatutu (Makna Dan Konsep Sosiologis-Kultural To Kaili) (Palu: Universitas Tadulako, 2007).
}

\footnotetext{
${ }^{28}$ Dona Evans, Kamus Kaili Ledo-Indonesia-Inggris (Central Sulawesi: Office of Culture and Tourism, 2003).

${ }^{29}$ Yunita Clara, "Makna Nosarara Nosabatutu (Analisis Semiotika Terhadap Tugu Nunu Dan Tugu Perdamaian)," Kinesik 5, no. 3 (2018): 120-131.
} 
Dwi Septiwiharti, Septiana Dwiputri Maharani, Rizal Mustansyir

painting is beautiful.' They see beauty as an inherent quality rather than as something derived from human perceptions.

Scheler, the main proponent of value objectivism, rejects theories of subjectivism. Value is not relational, but a particular quality. As such, experiences with values cannot be reduced to relational experiences. Scheler disagrees with Locke's idea (as partially supported by Kant) that values are not unique (constituent) elements of objects, but rather that forces, energies, and tendencies within objects can have similar effects. Scheler also rejects the argument that every value experience must stem from its effects. One of Scheler's relevant hypotheses is that values exist independently of their relationships, and thus can be perceived and experienced independently. ${ }^{32}$

Scheler views that values have their own $a$ priori qualities, qualities that exist independently. Values are thus no different than the objects associated without them. As a result of their independence, values are unchanging, absolute, not conditioned by outside activities and behaviors. Values are not relative; human knowledge is relative. For Scheler, truth is not found within the constellation of values. Scientific and cultural values become values through reference to them and the knowledge they imply. ${ }^{33}$

Scheler argues that values are organized within a specific a priori hierarchy, wherein certain values are prioritized over others through certain preferences - conscious, rather than empirical, activities. Axiology, thus, focuses on the preferences that underlie values and value systems. 'Preference' should not be confused with 'choice'; choice refers to a tendency, while preference is something consciously recognized, the result of a conscious decision. As such, the hierarchy of values is not shaped by human desires but exists independently of them. The correctness of decisions is determined by the prioritization of

\footnotetext{
${ }^{32}$ Frondizi, What Is Value? An Introduction to Axiology.

${ }^{33}$ Frondizi, What Is Value? An Introduction to Axiology.
}

The Concepts of Nosarara Nosabatutu in the Kaili Community: Inspiration for Religious Harmony in Indonesia

values that are higher in the value hierarchy, as seen through preferences. ${ }^{34}$

In determining a value position in Scheler's axiological hierarchy, specific criteriaendurance, character, basis, fundamentality, satisfaction, and relativity-are applied. Applying these criteria, Scheler delineates the following hierarchy. First, at the lowest level, are sensory pleasure and displeasure. Second are vital values, such as nobility, refinement, and roughness. Third are spiritual values, which exist independently of the physical and the environmental, and tend to be prioritized over vital values. Fourth - and highest in the hierarchy-are religious values, which exist independently and cannot be reduced to the spiritual.

Scheler's axiological objectivism rejects the arguments that values are relative, instead values exist independently of subjective understandings. He believes that unlimited values exist, independent of human senses and perceptions, and thus rejects that values are shaped by social reality. The facts of life do not affect values; rather, values are ideal objects, above all outside influences. Objective values exist within a hierarchy, wherein pleasure, vital, spiritual, and religious values exist. Vital values may include nobility and refinement, ignobility and roughness, and even good and evil. From these, values of social and personal welfare are derived. Spiritual values, meanwhile, are those that are perceived through one's spiritual sentiments and include such intangible values as love and hate. ${ }^{35}$

Positioned within the context of Scheler's hierarchy of values, the Kaili principle of nosarara nosabatutu may be identified simultaneously as vital and spiritual values. Vital values are independent of the values below them in the hierarchy (pleasure values) and of the values above them (spiritual and religious values). Reflecting the fact that human beings are simultaneously individual

\footnotetext{
${ }^{34}$ Wahana, Nilai Etika Aksiologi Max Scheler.

${ }^{35}$ Frondizi, What Is Value? An Introduction to Axiology.
} 
Dwi Septiwiharti, Septiana Dwiputri Maharani, Rizal Mustansyir

and social creatures, kinship and family are important values, essential elements of personal and community living. It is through values of kinship and solidarity that the Kaili create welfare and maintain social dignity.

The principle of nosarara nosabatutu also embodies spiritual values that occupy a higher position within the value hierarchy than pleasure and vital values. Spiritual values are perceived through a sense of spirituality and incorporate values of love and hate. Spiritual values exist within a hierarchy, as follows: (a) aesthetic values (beauty, ugliness, etc.), (b) values of justice and injustice, (c) pure knowledge of philosophical and scientific 'truth' (not correctness or incorrectness). ${ }^{36}$

Drawing on Scheler's hierarchy above, the principle of nosarara nosabatutu embodies spiritual values of love and hate through its emphasis on (a) a shared sense of struggle; (b) a respect for shared resources (natural, environmental, etc.) and intention to use them for shared interests; (c) a sense of secrecy; and (d) a sense of caution. As it not only promotes public welfare but also a shared understanding of ownership and belonging, the principle of nosarara nosabatutu simultaneously embodies vital and spiritual values.

Among the Kaili people, any possession can be provided to somebody who requires it. There is a sense of shared responsibility, one that needs shared resources to be honored, maintained, and otherwise utilized to promote the greater good. Furthermore, the principle teaches that secrecy and caution must be maintained; as all secrets must be kept, caution in speech and action is necessary. These spiritual values continue to be maintained and practiced by the Kaili through their principle of nosarara nosabatutu, in which harmony and solidarity are prioritized above all other. As such, through its embedded values, nosarara nosabatutu could offer a necessary means of shaping the character of the Indonesian nation and promoting nationalism and national integrity.
The Concepts of Nosarara Nosabatutu in the Kaili Community: Inspiration for Religious Harmony in Indonesia

\section{CONCLUSIONS}

Through their principle of nosarara nosabatutu, the Kaili people of Central Sulawesi have created a worldview that promotes social harmony and integrity. The term nosarara indicates a strong sense of kinship and family unity. At the same time, nosabatutu refers denotatively to a cloth bag or sack that is traditionally used to store resources that can be used for the public good. Using Scheler's hierarchy of values, the principle of nosarara nosabatutu can be defined as embodying vital and spiritual values that are manifested in the everyday activities and lives of the Kaili people.

As a principle that promotes kinship, solidarity, and harmony, nosarara nosabatutu embodies vital values that are used to maintain social welfare. The kinship embodied by nosarara also indicates a specific spiritual sentiment and preference, namely that human beings should love each other as kin, as reflected in the phrase sararata le/sararata ia ('our brother'/'our sister'). Meanwhile, the spiritual value of nosabatutu conveys a shared sense of responsibility, respect, and a willingness to promote the greater good, to maintain secrecy, and to exercise caution. It implies that social harmony and solidarity should be prioritized above all others.

This article has shown that, within a Schelerian hierarchy of values, nosarara exists at the vital level while nosabatutu exists at the spiritual level; however, both values convey spiritual sentiments and preferences. Nosarara teaches the Kaili that they must love each other as they love themselves, thereby reflecting Kaili's spirituality. Meanwhile, nosabatutu explains that communities must work together to maintain resources and to keep secrets. As all Kaili come from the same womb, they must live together as a family and share the same resources. This is a valuable inspiration for religious harmony in Indonesia.

\footnotetext{
${ }^{36}$ Frondizi, What Is Value? An Introduction to Axiology.
} 
Dwi Septiwiharti, Septiana Dwiputri Maharani, Rizal Mustansyir

\section{REFERENCES}

Bagus, Lorens. Kamus Filsafat. Jakarta: Gramedia Pustaka Utama, 1996.

Chalid, Syamsuddin H. Nosarara Nosabatutu (Makna Dan Konsep Sosiologis-Kultural To Kaili). Palu: Universitas Tadulako, 2007.

Clara, Yunita. "Makna Nosarara Nosabatutu (Analisis Semiotika Terhadap Tugu Nunu Dan Tugu Perdamaian)." Kinesik 5, no. 3 (2018): 120-131.

Daroeso, Bambang. Dasar Dan Konsep Pendidikan Moral Pancasila. Semarang: Aneka Ilmu, 1986.

Djafar, Suaib. Mengenal Adat Kaili Di Sulawesi Tengah. Yogyakarta: Ombak, 2012.

Duh, Helen I. "Antecedents and Consequences of Materialism: An Integrated Theoretical Framework." Journal of Economics and Behavioral Studies 7, no. 1 (2015): 20-35.

Evans, Dona. Kamus Kaili Ledo-IndonesiaInggris. Central Sulawesi: Office of Culture and Tourism, 2003.

Faisal, F, Abdul Munir Mulkhan, Achmad Nurmandi, and Hasse Jubba. "From Conflict to Assimilation: Strategies of Muslim Immigrants in Papua Special Autonomy Era." Wawasan: Jurnal Ilmiah Agama Dan Sosial Budaya 4, no. 1 (2019): 103-116.

Frondizi, R. What Is Value? An Introduction to Axiology. Chicago: Open Court Publishing Company, 1971.

Gazali, Dunia. Sejarah Dan Telaah Sastra Indonesia. Jakarta: Wijaya, 1971.

Haliadi. Nosarara Nosabatutu. Yogyakarta: Yogyakarta: Nuansa Aksara, 2008.

Hills, Michael D. "Kluckhohn and Strodtbeck's Values Orientation Theory." Online Readings in Psychology and Culture, no. 4 (2002). https://doi.org/10.9707/23070919.1040.

Kluckhohn, Clyde. "Universal Categories of Culture." In Culture: A Critical Review of Concepts and Definitions, edited by \& A. G. Meyer A. L. Kroeber, C. Kluckhohn, W. Untereiner. New York: Vintage Books,
The Concepts of Nosarara Nosabatutu in the Kaili Community: Inspiration for Religious Harmony in Indonesia

1963.

König, Anika. "Identity Constructions and Dayak Ethnic Strife in West Kalimantan, Indonesia." The Asia Pacific Journal of Anthropology 17, no. 2 (2016): 121-137.

Kristanto, Budi. Suku Bangsa Kaili Dari Sejarah Hingga Budayanya. Manado: Center for the Study of History and Traditional Values, 2002.

Mamar, Sulaiman. Perspektif Budaya. Jakarta: Rajawali Pers, 2009.

Mattulada, H.A. "Manusia Dan Kebudayaan Kaili Di Sulawesi Tengah." Majalah Ilmiah Gagasan, no. 3 (1985).

- Modal Personality Orang Kaili. Palu: Universitas Tadulako, 1989.

Melalatoa, Junus. Ensiklopedi Suku Bangsa Di Indonesia. Jakarta: C.V. Eka Putra, 1995.

Ratu, B, Misnah Misnah, and M Amirullah. "Peace Education Based on Local Wisdom Nosarara Nosabatutu." JOMSIGN: Journal of Multicultural Studies in Guidance and Counseling 3, no. 2 (2019): 106-118.

Saleh, Sukmawati. "Kearifan Lokal Masyarakat Kaili Di Sulawesi Tengah." Jurnal Academica 5, no. 2 (2013): 1126-34.

Scheler, Max. Der Formalismus in Der Ethik Und Die Materiale Wertehik. Halle: Verlag von Max Niemeyer, 1916.

Tanjung, Ida Liana, Bambang Purwanto, and Nur Aini Setyawati. "Colonial Politics in Forming Ethnic Identity of Melayu Minangkabau and Batak in Tapanuli." Jurnal Humaniora 28, no. 1 (2016): 106114.

Ullah, A K M Ahsan, and Hannah Ming Yit Ho. "Globalisation and Cultures in Southeast Asia: Demise, Fragmentation, Transformation." Global Society, 2020, 116.

Vansina, Jan. Tradisi Lisan Sebagai Sejarah. Yogyakarta: Ombak, 2014.

Wahana, Paulus. Nilai Etika Aksiologi Max Scheler. Yogyakarta: Kanisius, 2004. 